\title{
Оптимізація сумарної вартості теплового захисту приміщень та кліматичного обладнання
}

\author{
Н. В. Жихарєва, М. Г. Хмельнюк
}

Одеська національна академія харчових технологій, вул. Канатна, 112, Одеса, 65039

\begin{abstract}
Розроблено та обтрунтовано цільову функцію спільної оптимізації сумарної величини капітальних $i$ експлуатаційних витрат на тепловий захист приміщень $і$ кліматичне енергозберігаюче обладнання протягом терміну їх експлуатації. Наведена ијільва функція $\epsilon$ різницею початкових додаткових інвестицій в енергозберігаюче обладнання і додатковий тепловий захист і економії за 7 років експлуатації, отриманої від цьього обладнання $i$ посилення теплового захисту. Для практичного рімення задачі оптимізації в обчислювальному середовищі Маthcad розроблена програма математичного моделювання кліматичного режиму об'єкта, яка дозволяє за короткий відрізок часу при невеликих витратах отримати значення цільової функиї для варіантів комплектів обладнання спільно з варіантами теплового опору огороджень за час нормативного терміну експлуатації. В результаті були отримані терміни окупності варіантів енергозберігаючого обладнання $i$ величини економії, отриманої після досягнення моменту окупності до закінчення нормативного терміну. За результатами додаткового математичного моделювання, з урахуванням фактичних витрат енергї за перший рік роботи, можуть бути прийняті рекомендації, наприклад, по установці додаткового енергозберігаючого обладнання, посилення теплоізоляиії огороджень, скорочення періоду між чистками фільтра і т.д.
\end{abstract}

Ключові слова: Оптимізачія; Цільова функція; Енергозбереження; Кондиціювання повітря; Моделювання; Теплоізолячія; Рекуператор.

DOI: http://dx.doi.org/10.15673/ret.v53i4.706

(C) The Author(s) 2017. This article is an open access publication

This work is licensed under the Creative Commons Attribution 4.0 International License (CC BY)

http://creativecommons.org/licenses/by/4.0/

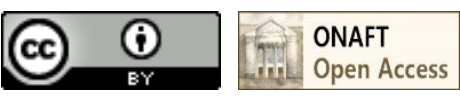

\section{1 Вступ}

Для вибору комплекту обладнання систем забезпечення мікроклімату в громадських об'єктах, що експлуатуються, доцільно проводити відповідне математичне моделювання.

Удосконалення ефективності програми енергозбереження $€$ однією 3 найважливіших державних завдань. Оптимізація (мінімізація) сумарної вартості капітальних і експлуатаційних витрат на забезпечення цілорічного мікроклімату в об'єктах громадського призначення є частиною цієї програми.

Чим краще тепловий захист приміщення, а це, як правило, означає більш високу вартість огорож, тим меншою продуктивністю може бути активна система забезпечення заданого мікроклімату, що веде до зниження ціни i експлуатаційних витрат на іiі функціонування

У даній роботі розроблена і обгрунтована цільова функція спільної оптимізації сумарної величини капітальних i експлуатаційних витрат на тепловий захист приміщень i кліматичне енергозберігаюче обладнання протягом терміну їх експлуатації.

Нижче наведено приклад математичного моделювання спільної оптимізація теплового захисту залу i рекуператора припливно-витяжної системи кондиціювання на ранній стадії проектування для приміщення, в якому цілий рік підтримується мікроклімат.

Моделювання виконано в середовищі Mathcad, Розрахунки виконуються за допомогою службових функцій [2].

\section{2 Цільова функція оптимізації сумарної вартості теплового захисту приміщень та кліматичного обладнання}

Практичне рішення задачі підвищення ефективності систем кондиціювання повітря залежить від математичного моделювання кліматичного режиму об'єкта, що дозволяє за короткий відрізок часу при невеликих витратах отримати значення цільової функції для варіантів комплектів обладнання спільно 3 варіантами теплового опору огороджень за час нормативного терміну експлуатації. В результаті повинні бути отримані терміни окупності варіантів енергозберігаючого обладнання і величини економії, отриманої після досягнення моменту окупності до закінчення нормативного терміну $[2,6]$.

Необхідно відзначити, що енергозбереження найбільш ефективно, якщо воно проводиться на всіх стадіях життєвого циклу об'єкта: від вибору на етапі проектування кліматичного обладнання та величини теплового опору огороджень, опрацювання доцільності 
використання поновлюваних джерел енергії, об'єктивного і висококваліфікованого енергоаудиту за результатами першого року експлуатації i енергоменеджменту до моменту капітальної модернізації об'єкта або його повної зупинки перед утилізацією обладнання [2, 3, 4, 5].

У цьому ключі за результатами першого року експлуатації бажано порівняти витрати електроенергії за лічильником 3 результатами розрахунків, що зумовили вибір енергозберігаючого обладнання i співвідношення витрат на пасивні (огорожі) і активні (обладнання) засоби забезпечення мікроклімату об'єкта.

За результатами додаткового математичного моделювання, з урахуванням фактичних витрат енергії за перший рік роботи, можуть бути прийняті рекомендації, наприклад, по установці додаткового енергозберігаючого обладнання, посилення теплоізоляції огороджень, скорочення періоду між чистками фільтра і т.д.

3 огляду на вище викладене нами запропонована i протестована наступна цільова функція спільної оптимізації теплового захисту об'єкта (теплового опору огороджень приміщення), в якому забезпечується заданий мікроклімат, і продуктивності енергозберігаючого кліматичного обладнання активної системи забезпечення цього мікроклімату. Цільова функція спільної оптимізації сумарної вартості теплової захисту приміщень та кліматичного обладнання, яке цілий рік забезпечують заданий мікроклімат.

Розроблена цільова функція є різницею початкових додаткових інвестицій в енергозберігаюче обладнання i додатковий тепловий захист i економії за 7 років експлуатації, отриманої від цього обладнання i посилення теплового захисту, яка забезпечує мінімум затрат.

$$
P t f=\min \left[\Delta P s t+P e s o b-\sum_{i=1}^{T} \frac{\Delta Q g}{(1+d-R)^{i}}\right],
$$

де $P t f$ - цільова функція для спільної оптимізації, пропонуємо визначати ії з урахуванням можливої зміни вартості електроенергії та коефіцієнта дисконтування валюти:

$\Delta P_{\mathrm{st}}$ - додаткова вартість утеплення зовнішніх огороджень 3 метою посилення теплового захисту приміщень із заданим мікрокліматом (це може бути одна зовнішня стіна або всі стіни зовнішні стіни для об'єкта, що стоїть окремо) [5];

$P_{\text {esob }}$ - витрати на покупку і установку в систему енергозберігаючого обладнання (наприклад, рекуператора або всього комплекту енергозберігаючого обладнання об'єкта);

$i$ - номер року після введення в експлуатацію енергозберігаючого обладнання;

$\Delta Q_{\mathrm{g}}-$ річна економія вартості споживаної електроенергії в результаті використання енергозберігаючого обладнання i посилення теплозахисту об'єкта (розраховується за середньомісячним температур зовнішньог середовища), кВт;

$d$ - річний коефіцієнт дисконтування національної валюти;
$R$ - коефіцієнт річного зростання вартості кВт * години.

Цільова функція (1), яка визначається для заданих варіантів за допомогою програми, виконаної в обчислювальному середовищі Mathcad, дозволяє виконати спільний оптимальний вибір варіанта теплового захисту об'єкта i комплекту енергозберігаючого обладнання об'єкта.

Цільова функція (1) має універсальний характер і може бути виконана для визначення терміну окупності.

Термін розрахункової експлуатації ( $T=7$ років) пропонується для подальшого обговорення. Прийнято вважати, що термін окупності енергозберігаючого обладнання, дорівнює терміну гарантії на це обладнання 2..4 роки, а термін отримання прибутку після терміну окупності, що дорівнює початковим інвестиціям в енергозберігаючі заходи, з урахуванням коефіцієнта дисконтування в межах $3 \ldots 5$ років. Використовувати термін служби на обладнання вентиляції та кондиціювання $15 \ldots 20$ років, наведений в ДБН В.2.5-67: 2013, в цільовій функції (1) нераціонально.

\section{3 Математичні аспекти оптимізації сумарної вартості теплового захисту приміщень та кліматичного обладнання}

Ця оціночна методика може бути використана для спільного вибору агрегату припливно-витяжної вентиляції з рекуперацією, інверторного кондиціонера i конструкції відповідних зовнішніх огороджень на ранній стадії проектування. При необхідності на стадії робочого проекту може бути виконаний перевірочний уточнений розрахунок, а за підсумками першого року експлуатації звірка уточненого розрахунку з витратою електроенергії за лічильником. В даному прикладі визначений термін окупності агрегатів з рекуперацією, обраний рекуператор, проведена спільна оптимізація капітальних і експлуатаційних витрат на розглянуті варіанти комплектів теплозахисту і енергозберігаючого обладнання за величиною цільової функції (1).

Визначення величин терміну окупності і цільової функції при використанні рекуператорів по середньомісячним температур визначається за кожний місяць.

Приведена оптимізація теплового захисту огородження приміщення, інверторного кондиціонера AOYG18LF фірми FUJITSU i рекуператора LGH50RX5-E cepiï Lossnay по цільовій функції (1).

Для кожного місяця ми визначаємо:

1. Потужність, яка необхідна для нагрівання без рекуператора припливного повітря до температури в приміщенні, Вт

$$
N=\frac{L}{3600} \rho\left(t_{s t}\right) \frac{d C\left(t_{s r i}\right)+d C\left(t_{x}\right)}{2}\left(t_{x}-t_{s r i}\right),
$$

де $t_{\text {sгі }},{ }^{\circ} \mathrm{C}$ середньомісячна температура зовнішнього повітря, $t_{\mathrm{x}}, \quad{ }^{\circ} \mathrm{C}$ температура повітря в $\mathrm{dCl}(\mathrm{t}):=\operatorname{interp}(\mathrm{S} 1, \mathrm{~T} 1, \Delta \mathrm{Cc} 1, \mathrm{t})$

Значення функції визначається ітераційними методом. 
2. Температуру припливного повітря після пластинчастого рекуператора, ${ }^{\circ} \mathrm{C}$

$$
t_{p i}=t_{s r i}+\eta_{p i}\left(t_{x}-t_{s r i}\right)
$$

3. Потужність, яка необхідна для нагрівання припливного повітря після пластинчастого рекуператора до температури в приміщенні, ВТ

$$
N=\frac{L}{3600} \rho\left(t_{s t}\right) \frac{d C\left(t_{p}\right)+d C\left(t_{x}\right)}{2}\left(t_{x}-t_{p}\right)
$$

4. Економію електроенергії, що витрачається на нагрівання припливного повітря при використанні пластинчастого рекуператора

$$
E_{k p i}=\frac{N_{1}-N_{p 1}}{1000} m \tau_{s} \cdot p e l
$$

де $\tau_{s}$, г / добу - тривалість роботи вентиляції на добу;

$m$ - кількість днів:

pel, грн - ціна 1 (кВт·год) електроенергії з ПДВ.

5. Сумарну річну економію витрат на електроенергію при використанні рекуператорів $\mathrm{Eg}$

$$
E g=\sum_{j=1}^{12} E g_{s}
$$

Визначення величин терміну окупності і цільової функції при використанні рекуператорів по середньомісячним температурам.

6. Термін окупності визначали з рівняння

$$
\frac{\text { Pesobi }}{E g i+\frac{E g i}{(1+d-R)^{2}}+\frac{E g i}{(1+d-R)^{3}}+\frac{E g i}{(1+d-R)^{4}} X I}=1
$$

де $\mathrm{XI}=\mathrm{Temp}(\mathrm{XI})$ - частка останнього року окупності рекуператора до моменту повної окупності.

7. Визначаємо значення цільової функції $\Delta P$ st за формулою (1) - додаткову вартість утеплення огороджень 3 метою посилення теплового захисту приміщення 3 заданим мікрокліматом (ізоляція + установка), грн. На оптимальні витрати впливає оптимальна товщина ізоляціі [5].

Визначаємо строк окупності доцільно-економічної ізоляції за формулою (7).

8. Методом кубічного сплайну визначаємо оптимальну товщину ізоляції.

\section{4 Результати оптимізаційного розрахунку су- марної вартості теплового захисту приміщень та кліматичного обладнання}

В даному прикладі визначений термін окупності агрегатів 3 рекуперацією, обраний рекуператор, проведена спільна оптимізація капітальних і експлуатаційних витрат на розглянуті варіанти комплектів теплозахисту i енергозберігаючого обладнання за величиною цільової функції (1).

На прикладі розглядається спільна оптимізація теплового захисту залу i рекуператора припливновитяжної системи кондиціювання на ранній стадії проектування для приміщення, в якому цілий рік підтримується мікроклімат м. Київ.

Попередньо були обрані за вищенаведеними вихідними даними агрегати 3 рекуперацією: VX 700E фірми Systemair (індекс параметрів в розрахунку - S) i LGH-50RX5-E cepiï Lossnay фірми Mitsubishi Electric [2].

Ціна агрегатів VX 700E та LGH-50RX5-E по прайслисту 2016 року $2960 \mathrm{Eu}$.

Сумарна річна економія витрат на електроенергію при використанні рекуператора VX 700E $\mathrm{EgS}=18373,19$ грн., а рекуператора LGH-50RX5-E $\mathrm{EgM}=23878,88$ грн. для умов Києву.

Визначили термін окупності по оптимізаційній формі для рекуператора VX 700E - 6,19 року, а для рекуператора LGH-50RX5-E - 3,31 року.

Попередньо визначений термін окупності.

Варіаційним методом розрахована цільова функція оптимізації при товщині ізоляції (приймали rookwool від $\delta=0,05$ до 2 з шагом 0,05) та отримали мінімальне значення функції (1).

При мінімальному значенні $P t f=87953$ грн. економія при терміні роботи 7 років.

Виконана кубічна сплайн-інтерполяція залежності величини цільової функції від товщини ізоляції стіни та отримано $\delta_{\text {опт }}=0,07 \mathrm{~m}$ при використанні енергоефективного обладнання LGH-50RX5-E.

\section{V. Висновок}

У даній роботі розроблена і обгрунтована цільова функція спільної оптимізації сумарної величини капітальних i експлуатаційних витрат на тепловий захист приміщень i кліматичне енергозберігаюче обладнання протягом терміну їх експлуатації .

Розроблена модель розрахунку оптимізації капітальних і експлуатаційних витрат на розглянуті варіанти комплектів теплозахисту і енергозберігаючого обладнання за величиною цільової функції 3 використанням цільової функції. На прикладі розглядається спільна оптимізація теплового захисту залу i рекуператора припливно-витяжної системи кондиціювання на ранній стадії проектування для приміщення, в якому цілий рік підтримується мікроклімат м. Київ. За розробленою програмою отримане оптимальне енергоефективне обладнання рекуператора LGH-50RX5-E 3 терміном окупності 3,2 року при оптимальній товщині ізоляції 0,07 , які забезпечують мінімальне значення цільової функції.

Результати математичного моделювання дозволяють визначити по середньомісячним зовнішнім температурам енергоефективне обладнання, яке при оптимальній товщині ізоляції огороджень забезпечує мінімум витрат та мінімальний строк окупності. На основі розробленої програми можливо оцінити кліматичне обладнання для будь-якого регіону i вибрати оптимальне 3 врахуванням доцільноекономічної товщини ізоляції.

\section{Литература}

1. Табунщиков Ю. А. Математическое моделирование и оптимизация тепловой эффективности 
зданий. [Текст] / Ю. А. Табунщиков, М.М. Бродач. М.: АВОК-ПРЕСС. - 2002. - 194 с.

2. Перепека В. И. Расчеты систем кондиционирования и вентиляции. / В. И. Перепека, Н.В. Жихарева Одесса: «ТЭС», 2014. - 240 с.

3. Жихарева Н. В. Оценка энергетической эффективности системы охлаждения плодоовощехранищ // Н.В.Жихарева, Хмельнюк М.Г. / Холодильна техника, 2015. - № 3. - С. 53-57

4. Жихарєва Н.В. Особливості розрахунку теплоприпливів в приміщенні при кондиціюванні повітря // Н.В.Жихарєва / Холодильна техніка і технологія. - 2015. - Том. 51, вип. 6-С. 17-20.

5. Жихарєва Н.В Економічно-доцільна товщина ізоляції сучасних ізоляційних матеріалів плодоовочесховищ // Н.В.Жихарєва, М. Г. Хмельнюк, О. В. Ольшевська / Холодильна техніка і технологія, 2015. - Том.51, вип. 3 - С. 22-25

6. Жихарєва Н.В. Математичне моделювання нестаціонарного теплообміну приміщень // Н.В.Жихарєва, М.Г.Хмельнюк / Холодильна техніка і технологія, 2016. - Том.52, вип. 6. - С. 75-77.

Отримана в редакції 10.05.2017, прийнята до друку 06.06.2017

\title{
Buildings Thermal Protection and Air Conditioning Equipment Overall Cost Optimization
}

\author{
N. V. Zhikhareva, M. G. Khmelniuk \\ Odessa National Academy of Food Technologies, 112 Kanatnaja str., Odessa, 65039, Ukraine
}

\begin{abstract}
The objective function of joint optimization of the overall amount of capital and operating costs for thermal protection of premises and climate-friendly energy-saving equipment during the period of their operation has been developed and justified. The given function is the difference between the initial additional investments in energy-saving equipment and additional thermal protection and savings for 7 years of operation received from this equipment and strengthening of thermal protection. For the practical solution of the optimization problem, a program of mathematical modeling of the climatic mode of the object was developed in the Mathcad computing environment, which allows, in a short period of time, at a small cost, to obtain the value of the objective function for variants of equipment sets in conjunction with the options for thermal resistance of the fences during the standard operating life. As a result, the payback period of energy-saving equipment options and the amount of savings obtained after reaching the payback period before the end of the regulatory period were obtained. Based on the results of additional mathematical modeling, taking into account the actual energy costs for the first year of operation, recommendations can be adopted, for instance, on installing additional energy-saving equipment, strengthening the thermal insulation of fences, reducing the period between cleaning the filter, etc.
\end{abstract}

Key words: Optimization; Objective Function; Energy; Air Conditioning; Modeling; Insulation; Heat Exchanger.

\section{References}

1.Tabunschykov YA, Brodach M.N. (2002) Matematycheskoe modelirovanie $i$ optimizatsia teplovoi effektivnosti zdanii. Moscow, Avok-PRESS, 194 p.

2.Perepeka V.I., Zhikhareva N.V. (2014) The calculations of air conditioning and ventilation. Odessa «TEC», $240 \mathrm{p}$.

3.Zhikhareva N.V. Khmelniuk M.G. (2015) Otsenka energeticheskoi effektivnosti sistemy ohlazhdeniia plodoovoschekhranilisch. Kholodilnaia tekhnika, No.3, 53-57.

4.Zhikhareva N.V. (2015) Calculating features of heat gain in an air conditioning room. Refrigeration Engineering and Technology, 51 (6), 17-20. DOI: http://dx.doi.org/10.15673/0453-8307.6/2015.44778
5.Zhikhareva N.V., Khmelniuk M.G., Olshevska O.V. (2015) Expedient-economic theckness of modern insulation material for fruit-vegetable warehouses Refrigeration Engineering and Technology, 51 (3), 22-25 DOI: http://dx.doi.org/10.15673/0453-8307.3/2015.39270

6.Zhikhareva N.V. Khmelniuk M.G. (2016) Mathematical modeling of building unsteady heat transfer. Refrigeration Engineering and Technology, 52 (6), 75-79. DOI: http://dx.doi.org/10.15673/ret.v52i6.479 